\title{
Influence Rules of Typical Plant Hedge in Purple Soil Areas on Soil Erodibility K-factor
}

\author{
JIANG Min ${ }^{1,2, \text { a }}$ NIE Wen-ting ${ }^{1,2}$ PAN Xiao-ying ${ }^{1,2}$ WANG Yifeng $^{1,2}$ XU \\ Wen-sheng ${ }^{1,2}$
}

\author{
${ }^{1}$ Yangtze River Scientific Research Institute of Changjiang River Water Resources Commission, \\ Wuhan, Hubei ,430010,China; ${ }^{2}$ Research Center on Mountain Torrent \& Geological Disaster \\ Prevention of Ministry of Water Resources, Wuhan, Hubei ,430010,China; ${ }^{a} 664288094 @ q q . c o m$
}

Fund Project, Central Non-Profit Scientific Research Fund For Institutes, CKSF2015013/TB, Influence Rules of Typical Plant Hedge in Purple Soil Areas on Soil Erosion and Sediment Yield

Keywords: Purple soil areas; plant hedge; corrodibility; influences

\begin{abstract}
In standard runoff plots with $10^{\circ}$ and $15^{\circ}$ slope croplands in purple soil areas, the paper studies influences of plant hedge on slope water and soil loss for slope croplands in purple soil areas under the natural rainfall conditions comprehensively and analyzes control actions of plant hedge's intervals arrangement on agricultural non-point source pollution. Change features of erodibility $\mathrm{K}$-factor and clay content are basically consistent. Generally speaking, plant hedge plays a role on erodibility K-factor and reflects as follows: vetiver grass plant hedge $>$ new horse tamarind, $10^{\circ}>15^{\circ}$. Erodibility K-factor has a significant positive correlation with soil sand grain content and microaggregate grain size $<0.002 \mathrm{~mm}$ dispersion coefficient. The correlation coefficients are 0.980 and 0.836 , respectively. It has a significant negative correlation with soil particles, clay particles, organic carbon content, degree of aggregation and fractal dimension of soil particles, and the correlation coefficients are $-0.925,-0.833,-0.787,-0.716$ and -0.807 , respectively. Soil sand grain content, particles, clay particles, organic carbon, organic content and degree of aggregation have the closest correlation with erodibility K-factor. Moreover, the high-low content of organic matter and clay content are effective index reflecting strong or weak soil anti-erosion ability.
\end{abstract}

\section{Introduction}

Purple soil areas in China have higher soil fertility and abundant hydrothermal resources and are important base of agricultural production, because purple soil areas have larger population density and high-strength utilization of sloping fields. Soil erosion in purple soil areas is serious, followed by the loess areas in China ${ }^{[1,2]}$. Human activities are dominant factors of intensifying or reducing soil erosion. Aiming at serious soil erosion and degeneration in purple soil slops, carrying out artificial planting and soil and water conservation measures plays the important significance on influence study of soil erosion, governing soil erosion of sloping fields, and utilizing purple slop soil resources rationally. Plant hedge not only control conservation of soil and water, but also improve soil nutrient status, as well as regulate agricultural microclimate, and so on. It is equipped with good ecological, economic and social benefits and is an important agricultural and biological measure for governing water and soil loss of slope croplands in purple soils.

The paper analyze influence effects and influence mechanism of plant hedge on water and soil properties of purple soil from overground part to underground part of plant pledge, from groups to individuals and from macroscopic aspect to microcosmic aspect. These studies are not common in overseas. Based on the new horse tamarind, the study applies standard runoff plots $\left(15^{\circ}\right)$ to test five standard runoff plots and reflects changes of erodibility K-factor under the natural rainfall conditions of erosion areas. The research proves that plant hedge has an obvious improvement effect on soil anti-erodibility of southern hill slope filed in red soils. Thus, water and soil loss is obviously controlled. Moreover, plant hedge technology controlling soil erosion both is equipped with ecological benefits and economic benefits. It is deserved to be greatly applied in the prevention and control process of water and soil loss in slope croplands. 


\section{Materials and Methods}

\section{Overview of Test Areas}

5 standard runoff plots in the test areas were selected. Their slope surface faced to the south. Soils belonged to reddish-brown purple soil. Parent materials were shale and medium soils. Plot gradient with the number of 1, 2 and 3 was 10. Plot gradient with the number of 4 and 5 was skillful. Plots with the number of 1, 3 and 5 were new horse tamarind (Leoeaen, leueochala, mimosa), vetiver grass, and vetiver grass plant hedge. Interband crop(corn) planting pattern adopted smooth conventional planting. No. 2 and No. 4 had no plant plot crop(corn) planting pattern and was the same to No.1, No. 3 and No. 5 plots. No. 2 had no plant hedge plot, which was the control area of No.1 and No.3 plant hedge plots, respectively. No. 4 had no plant hedge plot, which was the control plot with the plant hedge plot. New horse tamarind and vetiver grass plant hedge were planted in the spring of 2010 . They have been planted for over 6 months until the last soil sampling for the study. After a rainy season (May-September), crops have grown for a season. The planting way of vetiver grass and new horse tamarind planting was transplant. At the initial stage of planting, it has had the height of $30 \mathrm{~cm}$ and was transplanted in April 2010. Vetiver grass plant hedge has been planted over 6 months until the last soil sampling in October 2010. During the period, it has experienced a rainy season (May-September). The plant height has already had $60 \mathrm{~cm}$. Crops in standard runoff plots in the test areas were corns. In order to eliminate influences of fertilization level on testing results, fertilization time and level in every plot were the same. Nitrogenous fertilizer $(\mathrm{N})$, phosphatic fertilizer (PZos) and potash fertilizer on May $22^{\text {nd }}$ in every plot were $1.6 \mathrm{~kg}, 1.6 \mathrm{~kg}$ and $0 \mathrm{~kg}$. Fertilizing amount on July $5^{\text {th }}$ in every plot was $0.4 \mathrm{~kg}, 0 \mathrm{~kg}$ and $0 \mathrm{~kg}$, respectively. Plant hedge planting mode was three-band plant hedge in line with slope position of plots. New horse tamarind plant hedge was 2 lines; width of plant hedge band for every line was $0.50 \mathrm{~m}$. Line spacing was $20 \mathrm{~cm}$. Row spacing was $20 \mathrm{~cm}$. Plant hedge for every band left $1.00 \mathrm{~m}$ of isolation belt with crops. Therefore, No. 1, No.3 and No.5 had plant hedge slope surfaces. The band length of every hedge was $6.27 \mathrm{~m}, 6.27 \mathrm{~m}$ and $6.40 \mathrm{~m}$, respectively.

Testing Methods

Artificial rainfall adopted combined over-head shower. The shower nozzle was the American SPRACO cone shower nozzle. The rainfall height was $4.75 \mathrm{~m}$. Water supply pressure was $0.08 \mathrm{MPa}$. Changing the number and combination of rainulator could obtain different raininess. Pressure control system and valve can control rainfall intensity and distribution of raindrop particles, making it close to natural rainfall. Within 1.0, 1.5 and $2.0 \mathrm{lnn}$ min of three rainfall intensity, overland runoff and interflow were collected every $6 \mathrm{~min}$, $4 \mathrm{~min}$ and $3 \mathrm{~min}$, so as to ensure rainfall of every runoff sample was $6 \mathrm{~mm}$. After measuring volume, direct surface runoff samples were stirred. $500 \mathrm{ml}$ was collected to filter. Samples were dried to measure sediment charge in runoff. Calculation formulas of runoff strength $\mathrm{q}(\mathrm{mm} / \mathrm{h})$, runoff coefficient $\mathrm{q}_{\mathrm{c}}(\mathrm{mm})$ and soil erosion $\mathrm{er}\left(\mathrm{g} / \mathrm{m}^{2} . \mathrm{h}\right)$ were shown as follows:

$$
\begin{gathered}
q=\frac{S V}{S . T} \\
q_{c}=\frac{V_{t}}{R \cdot T_{0} \cdot S} \\
e r=\frac{G \cdot V \cdot 10^{-4}}{T \cdot S}
\end{gathered}
$$

V was the runoff volume collected in the plastic bucket at every interval. S, T (h) was the collected interval time; $\mathrm{V}(\mathrm{t})$ was the runoff volume collected by rainfall. $\mathrm{R}$ was the total time for every rainfall, and $\mathrm{G}(\mathrm{g} / \mathrm{Inm} 3)$ was sediment charge in runoff sample.

Fresh soil was screened by $2 \mathrm{~mm}$ to move stone and plant root system in soil. Bacteria, fungus and actinomycetes in soil applied to dilute plate count ${ }^{[5]}$. Chloroform fumigation extraction method was applied to measure microbial biomass carbon and nitrogen ${ }^{[6]}$. Chloroform fumigation extraction was cultivated for $24 \mathrm{~h}$ under $25^{\circ} \mathrm{C}$ of vacuum condition. Extract liquid was extracted to apply $0.5 \mathrm{~mol}^{-1}$ K2SO4 solution (1:2, ratio of clay to water). Soil organic carbon measurement applied potassium dichromate heating method ${ }^{[7]}$. Soil respiration intensity used alkali absorption method titration [144]. 
Metabolic quotient was the specific value between soil respiration intensity and microbial biomass carbon.

Soil water content feature was measured by cutting-ring method. Social organic content applied potassium dichromate heating method to measure. Measurement of soil total nitrogen applied semimicro Kelvin method. Soil total phosphorus applied HCIO4-H2504 method. Rapid available phosphorus utilized similar colorimetric method of total phosphorus. Total potassium and rapidly available potassium in soil applied flame photometer.

Data Analysis Method

Data analysis method mainly includes simple variance analysis, principal component analysis and $\mathrm{K}$-mean value clustering analysis. Variance analysis includes one-way analysis of variance and two-way analysis of variance considering interaction. One-way analysis of variance only considers influences of one-way factors on test index, while two-way analysis of variance considers influences of two factors and influences of their interaction on testing results. Multiple comparisons in variance analysis apply least significant difference (LSD). $\mathrm{P}<0.05$ of significance level is obvious, and $\mathrm{P}<0.01$ is extremely significant. Different significance level is marked with different letters.

\section{Influences of Plant Hedge on Erodibility}

Changing Features of Erodibility K-factor

Erodibility mainly refers to the ability to disperse and suspend soil water resistance and is one of important parameters to evaluate soil erosion resistance ability. Generally speaking, it is measured by using erodibility K-factor. The size refers the complexity of soil erosion, reflecting vulnerability and sensibility of soil erosion external agent denudation and transportation. It is an internal factor of impacting soil loss amount and also is the foundation on studying soil erosion. The study utilized soil particle composition and soil organic carbon to estimate soil erodibility K-factor through EPIC, analyzed and studied influences of erodibility, and provided basis on controlling water and soil loss, improving soil anti-erosion ability and controlling agricultural non-point source pollution for slope croplands in purple soil.

It can be observed from Table 1 and Table 2 that variation of erodibility K-factor in five plots was $-0.0042,0.0015,-0.0058,0.0032$ and 0.006 , respectively by comparing with the background values, indicating that erodibility K-factor in No.1 and No.3 plots by planting hedge was reduced with varying degrees. K-factor in the No.5 plot and the control group was increased with varying degrees and was basically consistent with the change features of clay particles, namely the control key of water and soil loss in purple soil is to control soil clay content on the slope surface. Because the smaller soil erodibility K-factor is, the soil anti-erosion ability will be stronger, namely soil erosion of slope surface is lower. Therefore, from the perspective of data analysis, influences of plant hedge on slope surface's soil erodibility were shown as follows: vetiver grass plant hedge $>$ new horse tamarind, $100>15$. The size of erodibility may be commonly restrained by multiple factors, such as soil humus content and aggregate content, etc. However, influences of plant hedge on the size of erodibility also need to increase age limit of plant hedge and further conduct long-term testing study.

Table 1. Erodibility K-factor of Subsoil Samples in Plots before Planting

\begin{tabular}{ccccccc}
\hline Plots & SN(\%) & SIL(\%) & CLA(\%) & SNI & C $(\%)$ & $\mathrm{K}_{\text {epic }}\left(t \cdot h m^{2} \cdot h \cdot M J^{-1} \cdot m^{-1} \cdot h m^{2}\right.$ \\
& & & & & & 0.0914 \\
\hline 1 & 44.16 & 44.48 & 11.37 & 0.5584 & 0.6976 & 0.0913 \\
2 & 43.70 & 38.82 & 17.48 & 0.5630 & 0.6516 & 0.0842 \\
3 & 39.79 & 45.26 & 14.95 & 0.6021 & 0.7520 & 0.0803 \\
4 & 35.68 & 47.41 & 16.91 & 0.6432 & 0.6492 & 0.0808 \\
5 & 35.42 & 48.99 & 15.78 & 0.6476 & 0.6246 & \\
\hline
\end{tabular}


Table 2 Erodibility K-factor of Soil Samples after Rainy Season in Plots for Plant Hedge

\begin{tabular}{ccccccc}
\hline Plots & SN(\%) & SIL(\%) & CLA(\%) & SNI & C (\%) & $\mathrm{K}_{\text {epic }}\left(t \cdot h m^{2} \cdot h \cdot M J^{-1} \cdot m^{-1} \cdot h m^{2}\right.$ \\
& & & & & & 0.0872 \\
\hline 1 & 41.13 & 46.27 & 12.60 & 0.5887 & 0.7024 & 0.0928 \\
2 & 44.26 & 38.37 & 17.37 & 0.5574 & 0.6235 & 0.0784 \\
3 & 35.43 & 47.62 & 16.96 & 0.6457 & 0.7818 & 0.0835 \\
4 & 38.13 & 45.93 & 15.94 & 0.6187 & 0.5954 & 0.0814 \\
5 & 35.79 & 48.08 & 16.13 & 0.6421 & 0.5942 & \\
\hline
\end{tabular}

Erodibility and Soil Physical Property

Based on erodibility variables, mechanical composition, and microaggregate, etc., an influence in plots as well as variables of corresponding background values, SPSS was utilized to do Pearson correlation analysis.

It can be observed from Table 3 that erodibility K-factor variable and soil particle size of $0.25-0.05 \mathrm{~mm}$ quality content presented significantly positive correlation. The correlation coefficient was $0.5 \%$, indicating that the higher sand grain content is, soil particles will be loose, and it is not easy to form a relatively stable aggregate structure. It presented negative correlation with the grain size of $2-1 \mathrm{~mm}, 1-0.25 \mathrm{~mm}, 0.05-0.021 \mathrm{~mm}, 0.02-0.002 \mathrm{~mm}$, and $<0.002 \mathrm{~mm}$ mass fraction. Moreover, it also presented significant negative correlation with $0.05-0.0211 \mathrm{~mm}$ and $<0.002 \mathrm{~mm}$ mass fraction. Correlation coefficient was -0.808 and -0.833 , respectively.

Table 3 Correlation Analysis of Erodibility K and Soil Mechanical Composition

\begin{tabular}{cccccccc}
\hline & $\begin{array}{c}\text { Erodibilit } \\
\mathrm{y}\end{array}$ & $\begin{array}{c}2-1 \\
\mathrm{~mm}\end{array}$ & $\begin{array}{c}1-0.25 \\
\mathrm{~mm}\end{array}$ & $\begin{array}{c}0.25-0.05 \\
\mathrm{~mm}\end{array}$ & $\begin{array}{c}0.05-0.02 \\
\mathrm{~mm}\end{array}$ & $\begin{array}{c}0.02-0.002 \\
\mathrm{~mm}\end{array}$ & $\begin{array}{c}<0.002 \\
\mathrm{~mm}\end{array}$ \\
\hline Erodibility & 1 & & & & & & \\
$2-1 \mathrm{~mm}$ & -0.275 & 1 & & & & & \\
$1-0.25 \mathrm{~mm}$ & -0.230 & $0.497^{* *}$ & 1 & & & & \\
$0.25-0.05 \mathrm{~mm}$ & $0.596^{* *}$ & $0.780^{* *}$ & -839 & 1 & & & \\
$0.05-0.02 \mathrm{~mm}$ & $-0.808^{* *}$ & 0.096 & 0.197 & $-0.447^{*}$ & 1 & & \\
$0.02-0.002 \mathrm{~mm}$ & -0.147 & 0.274 & 0.030 & -0.176 & -0.341 & 1 & \\
$<0.002 \mathrm{~mm}$ & $-0.833^{* *}$ & 0.259 & 0.296 & $-0.582^{* *}$ & $0.585^{* *}$ & 0.024 & 1 \\
\hline
\end{tabular}

Notes: In the table, $*$ stands for 0.05 significant level; $* *$ stands for 0.01 significant level

It can be observed from Table 4 that erodibility K-factor variable presented positive correlation with the grain size of $0.25-0.05 \mathrm{~mm}$ and $0.05-0.02 \mathrm{~mm}$ mass fraction for soil microaggregate. Correlation coefficient was 0.054 and 0.314 , respectively. In addition, it also presented negative correlation with the grain size of $2-1 \mathrm{~mm}, 1-0.25 \mathrm{~mm}, 0.02-0.002 \mathrm{~mm}$ and $<0.002 \mathrm{~mm}$ mass fraction. It presentative significant negative correlation with the $2-1 \mathrm{~mm}$ and $<0.002 \mathrm{~mm}$ mass fraction. Correlation coefficient was -0.524 and -0.374 , respectively, indicating that the increase of grain size $>1 \mathrm{~mm}$ and $<0.002 \mathrm{~mm}$ microaggregate mass fraction in soil microaggregate was not beneficial to form relatively stable aggregate, but reduced soil anti-erosion ability.

Table 4 Correlation Analysis of Erodibility K-factor and Soil Microaggregate

\begin{tabular}{cccccccc}
\hline & $\begin{array}{c}\text { Erodibilit } \\
\mathrm{y}\end{array}$ & $\begin{array}{c}2-1 \\
\mathrm{~mm}\end{array}$ & $\begin{array}{c}1-0.25 \\
\mathrm{~mm}\end{array}$ & $\begin{array}{c}0.25-0.05 \\
\mathrm{~mm}\end{array}$ & $\begin{array}{c}0.05-0.02 \\
\mathrm{~mm}\end{array}$ & $\begin{array}{c}0.02-0.002 \\
\mathrm{~mm}\end{array}$ & $\begin{array}{c}<0.002 \\
\mathrm{~mm}\end{array}$ \\
\hline $\begin{array}{c}\text { Erodibility } \\
\text { 2-1mm }\end{array}$ & $-0.524^{* *}$ & 1 & & & & & \\
$1-0.25 \mathrm{~mm}$ & -0.062 & $0.366^{* *}$ & 1 & & & & \\
$0.25-0.05 \mathrm{~mm}$ & $0.054^{* *}$ & $0.568^{* *}$ & $-0.513^{* *}$ & 1 & & & \\
$0.05-0.02 \mathrm{~mm}$ & -0.314 & -0.054 & -0.071 & $-0.691^{* *}$ & 1 & & \\
$0.02-0.002 \mathrm{~mm}$ & -0.226 & 0.172 & 0.306 & -0.045 & -0.359 & 1 & \\
$<0.002 \mathrm{~mm}$ & $-0.374^{*}$ & $0.364^{*}$ & 0.162 & -0.235 & 0.063 & 0.101 & 1 \\
\hline
\end{tabular}




\section{Influence Analysis of Erodibility K-factor}

Through erodibility in plots and variations of the corresponding background values with sand, particle, clay particle, organic carbon, Microaggregate grain size $<0.002 \mathrm{~mm}$ dispersion system, soil particle fractal dimension, etc., factors, SPSS was utilized to do Pearson correlation analysis. It can be observed from Table 5 that erodibility K-factor presented significant positive correlation with soil sand content and Microaggregate grain size $<0.002 \mathrm{~mm}$ dispersion coefficient. The correlation coefficient was 0.980 and 0.836 , respectively. Moreover, it presented significant negative correlation with soil particles, clay particles, organic carbon content, degree of aggregation and soil particle fractal dimension. Correlation coefficient was $-0.925,-0.833,-0.787,-0.716$ and -0.807 , respectively, indicating that particle and clay particle content in soil can improve soil structure and reduce erodibility, so as to increase soil anti-erosion ability. Reduction of soil sand content and dispersion coefficient can weaken erodibility and also increase soil anti-erosion ability.

Table 5 Correlation Analysis Table of Erodibility K and Influence Factors

\begin{tabular}{|c|c|c|c|c|c|c|c|c|}
\hline & $\begin{array}{l}\text { Erodibil } \\
\text { ity }\end{array}$ & $\begin{array}{c}\text { Sand } \\
\text { particle }\end{array}$ & Particle & $\begin{array}{c}\text { Clay } \\
\text { particle }\end{array}$ & $\begin{array}{l}\text { Organic } \\
\text { carbon }\end{array}$ & $\begin{array}{l}\text { Dispersi } \\
\text { on } \\
\text { coeffici } \\
\text { ent }\end{array}$ & $\begin{array}{l}\text { Degree } \\
\text { of } \\
\text { aggrega } \\
\text { tion }\end{array}$ & $\begin{array}{c}\text { Frac } \\
\text { tal } \\
\text { dim } \\
\text { ensi } \\
\text { on }\end{array}$ \\
\hline Erodibility & 1 & & & & & & & \\
\hline Sand particle & $\begin{array}{c}-0.980 * \\
*\end{array}$ & 1 & & & & & & \\
\hline Particle & $\begin{array}{c}-0.925 * \\
*\end{array}$ & $0.931 * *$ & 1 & & & & & \\
\hline Clay particle & $0.833 * *$ & $0.867 * *$ & $-0.624 * *$ & 1 & & & & \\
\hline Organic carbon & $\begin{array}{c}-0.787 * \\
*\end{array}$ & $-0.776^{* *}$ & $-0.610^{*}$ & $-0.825 * *$ & 1 & & & \\
\hline Dispersion coefficient & $\begin{array}{c}-0.836^{*} \\
*\end{array}$ & $0.854 * *$ & $0.718 * *$ & $-0.845^{* *}$ & $-0.752 * *$ & 1 & & \\
\hline Degree of aggregation & $-0.716^{*}$ & $0.749 *$ & $0.610 * *$ & $-0.769 * *$ & $0.631 * *$ & $0.801 * *$ & 1 & \\
\hline Fractal dimension & $\begin{array}{c}-0.807 * \\
*\end{array}$ & $0.828 * *$ & $0.709 * *$ & $0.801 * *$ & 0.731 & $0.774 * *$ & $0.759 * *$ & 1 \\
\hline
\end{tabular}

In order to confirm the most basic influences and effective index of erodibility in purple soil areas, eliminate mutual influences between influence factors, and ensure correlation coefficient between factors can reflect correlation degree between erodibility and factors really, the study conducted partial correlation analysis of erodibility and influences. It can be observed from Table 6-6 that soil sand particle, particle, clay particle, organic carbon, organic content and degree of aggregation with erodibility had the closest relation. As a kind of cement substance, soil organic matter is one of important chemical properties in soil. High-low content of organic content plays an important influence on stability of soil aggregate. Moreover, loss of organic matter is transferred from soil particles and lost by runoff, so as to impact soil anti-erosion ability. It can be observed that strength and weakness of erodibility in essence depends on soil organic content, while soil degree of aggregation not only is impacted by soil aggregate content, but also is impacted by soil clay content, indicating that organic matter and high-low clay content are effective index of reflecting strong or weak soil anti-erosion ability. Therefore, in the ecological environment construction of purple soil areas, plant hedge has a positive role on generating slope surface runoff and controlling soil particle migration, maintaining soil clay content of slope surface, improving soil organic content, promoting formation of soil aggregate, and increasing soil degree of aggregation. Plant hedge measure is an 
effective approach to reduce erodibility in slope croplands and increase soil anti-erosion ability of soil surface.

Table 6 Partial Correlation Analysis of Erodibility K-factor and Influences

\begin{tabular}{lcccccc}
\hline Erodibility & $\begin{array}{l}\text { Sand } \\
\text { content }\end{array}$ & Particle content & Clay content & Organic content & $\begin{array}{l}\text { Organic carbon } \\
\text { content }\end{array}$ & $\begin{array}{l}\text { Degree } \\
\text { aggregation }\end{array}$ \\
\hline Correlation coefficient & 0.933 & -0.850 & -0.430 & -0.437 & -0.437 & -0.140 \\
Significance probability level & 0.01 & 0.01 & 0.02 & 0.18 & 0.18 & 0.47 \\
\hline
\end{tabular}

\section{Conclusions}

By carrying out standard runoff plots with $10^{\circ}$ and $15^{\circ}$ slop croplands in purple soils, plant vetiver grass and new horse tamarind plant hedge suffered from a rainy season. After planting, Different plant hedge conducted testing study on nutrient loss, water and soil loss and agricultural non-point sources on the slope surface and combined with analysis of observational data in runoff plots, the study aimed at influences of water and soil loss and soil erosion on the slope surface of plant hedge in slope croplands under the conditions of studying natural rainfall, as well as control effect of arranging plant hedge spacing and agricultural non-point source pollution, so as to provide a new reference basis on arranging hedge zone in purple soil areas, preventing water and soil loss, and controlling non-point sources. Through the analysis, the following conclusions can be obtained:

(1) Erodibility had the positive correlation with $0.25-0.05 \mathrm{~mm}$ of soil particle diameter mass change. The correlation coefficient was 0.596 . It presented negative correlation with $2-1 \mathrm{~mm}, 1-0.25$, $0.05-0.02 \mathrm{~mm}, 0.02-0.002 \mathrm{~mm}$ and $<0.002 \mathrm{~mm}$ mass fraction and showed significant negative correlation with $0.05-0.02 \mathrm{~m}$ and $<0.002 \mathrm{~mm}$ mass fraction. The correlation coefficient was -0.808 and -0.833 , respectively. Erodibility $\mathrm{K}$-factor presented positive correlation with $0.25-0.05 \mathrm{~mm}$ and $0.05-0.02 \mathrm{~mm}$ of soil Microaggregate mass fraction. The correlation coefficient was 0.054 and 0.314 , respectively. It presented negative correlation with the grain size of $2-1 \mathrm{mml}, 1-0.25 \mathrm{~mm}$, $0.02-0.002 \mathrm{~mm}$ and $<0.002 \mathrm{~mm}$ mass fraction and showed significant negative correlation with $2-1 \mathrm{~mm}$ and $<0.002 \mathrm{~mm}$ mass fraction. Correlation coefficient was -.0524 and -0.374 , respectively, indicating that the increase of soil micraggregate's grain size was not beneficial to form stable aggregate and reduce soil anti-erosion ability on the contrary.

(2) Erodibility K-factor was basically consistent with change features of clay content, indicating that the control key of slope surface's water and soil loss in purple soil areas is to control soil clay content on the slope surface. The influence role of plant hedge on slope surface's erodibility K-factor was reflected as: vetiver grass plant hedge $>$ new horse tamarind, $100>15^{\circ}$. Erodibility K-factor presented significant positive correlation with soil clay content and $0.002 \mathrm{~mm}$ dispersion coefficient of Microaggregate. The correlation coefficient was 0.980 and 0.836 , respectively. It presented significant negative correlation with soil particle, clay particle and organic carbon content and soil particle fractal dimension. The correlation coefficient was $-0.925,-0.833,-0.787,-0.716$ and -0.807 , respectively, indicating that plant hedge measure increases particle and clay content in soil or reduce soil clay content and dispersion coefficient, so as to reach the purpose of reducing erodibility and improving social anti-erosion ability. Soil clay particles, particles, clay particles, organic carbon and organic content and degree of aggregation have the closest correlation with erodibility. Moreover, organic matter and high-low clay content are effective index of reflecting strong and weak soil anti-erosion ability.

\section{References}

[1] Pu Chongfeng, Cai Qiangguo, Chen Qinjuan, Wu Shuan, Fan Yuntao and Ma Yan, Testing Study on Surface Soil Growth Characteristics in Purple Soil, Journal of Soil, Vol 44, 2007, pp.385-39;

[2] Cai Qiangguo, Zhu Yuanda and Wang Shiying, Rill Erosion Process and Its Influences of Soil, Advances in Water Science, Vol., 15, 2004, pp11-18; 
[3] Ding Wenfeng, Zhang Pingcang and Wang Yifeng, Testing Study on Interflow Formation of Slope Surface and Erosion Sedimentation of Slope Surface in Purple Soil, Journal of Yangtze River Academy of Science, Vol.25, 2008, pp.14-17;

[4] Lin Chaowen, Tu Shihua and Huang Jingjing, et al., Influences of Plant Hedge on Water and Soil Loss and Soil Fertility of Slope Croplands in Purple Soil Areas, Journal of Ecology, Vol., 26, 2007, pp.2191-2198;

[5] Wang Haiming, Chen Zhijian, Liao Xiaoyong, Li Xianwei and Chen Yixiang, Influences of Plant Hedge Technology in Slope Croplands in Three Gorges Reservoir Region on Soil Properties, Anhui Agricultural Science, Vol., 37(2), 2009, pp. 692-694;

[6] Lin Chaowen, Tu Shihua and Huang Pinpin, et al., Influences of Plant Hedge on Water and Soil Loss and Soil Fertility of Slope Croplands in Purple Soil Areas, Journal of Ecology, Vol.26(6), 2007, pp.2191-2198;

[7] Tu Shihua, Chen Yibing and Zhu Qing, et al., Roles and Effects of Economic Plant Hedge on Preventing and Controlling Water and Soil Loss of Slope Croplands in the Upper Yangtze River, Journal of Water and Soil Maintenance, Vol. 19(6), 2005, pp 1-5;

[8] Shi Xiaomei, Shi Dongmei, and Wen Zhuoli, The Feature Study on Different Land Utilization Types' Soil Anti-Erodibility in Purple Hilly Areas, Jorunal of Water and Soil Maintenance, Vol.21(4), 2007, pp.63-66;

[9] Dong Youpu, The Study on Water and Soil Loss under Different Processing of Plant Hedge in Southern Hill and Mountains, Hefei: Anhui Agricultural University, 2009, pp.19-21;

[10] Nie Jun, Liao Yulin and Xie Jian, et al., Influences of Vetiver Grass Biological Hedge on Soil Direct Surface Runoff and Nitrogen Loss in Vegetable Plots under Natural Rainfall Conditions; Journal of Water and Soil Maintenance, Vol., 23(2), 2009, 12-16 